\title{
Formulasi Sampo Ekstrak Daun Teh Hijau (Camellia sinensis var. assamica)
}

\author{
Lia Suryati ${ }^{1}$, Nyi M. Saptarini ${ }^{2}$ \\ ${ }^{1}$ Jurusan Farmasi, FMIPA, Universitas Al Ghifari, Bandung, Indonesia \\ ${ }^{2}$ Fakultas Farmasi Universitas Padjadjaran, Sumedang, Jawa Barat, Indonesia
}

\begin{abstract}
Abstrak
Sampo digunakan untuk menghilangkan partikel yang tidak diinginkan, seperti minyak dan ketombe. Daun teh terbukti mempercepat pertumbuhan rambut. Penelitian ini bertujuan membuat sampo ekstrak daun teh hijau (Camellia sinensis var. assamica) dari Pusat Penelitian Teh dan Kina Gambung (Jawa Barat) yang stabil dan aman. Tahapan penelitian meliputi ekstraksi, penapisan fitokimia, formulasi sampo, uji stabilitas fisik meliputi organoleptik, $\mathrm{pH}$, bobot jenis, viskositas, dan uji iritasi. Sampo diformulasikan dengan konsentrasi 5, 10, dan 15\% ekstrak daun teh hijau dengan dan tanpa PEG-400 berdasarkan hasil orientasi viskositas sampo. Ekstraksi menghasilkan rendemen sebesar 35\%. Penapisan fitokimia menunjukkan simplisia dan ekstrak mengandung alkaloid, flavonoid, dan tanin. Sampo ekstrak daun teh hijau berwarna coklat muda yang homogen dengan rentang $\mathrm{pH}$ 5,2-6,7, bobot jenis sebesar 0,93-1,10 g/ $\mathrm{mL}$, viskositas 1230-3910 cps, serta tidak mengiritasi kulit dan mata. Seluruh formula sampo memenuhi kriteria sampo yang baik. Formula $\mathrm{F}$ dipilih sebagai formula terbaik, karena mengandung konsentrasi ekstrak paling tinggi $(15 \%)$ dan mentol.
\end{abstract}

Kata kunci: Metabolit sekunder, stabilitas fisik, uji iritasi

\section{Shampoo Formulation Of Green Tea Leaves Extract (Camellia sinensis var. assamica)}

\begin{abstract}
Shampoo used to remove the unwanted substances, like oil and dandruff. The tea leaves have shown to accelerate the hair growth. This aims of this study was to make shampoo of green tea leaves extract (Camellia sinensis var. assamica) from the Research Center of Tea and Quinine Gambung (West Java) which stable and secure. The steps of this study consist of extraction, phytochemical screening, formulation of shampoo, physical stability test i.e organoleptic, $\mathrm{pH}$, density, and viscosity, and irritation test. Shampoo formulated in 5, 10, and 15\% of green tea leaves extract with and without PEG- 400 based on the orientation of the shampoo viscosity. The yield of extraction was $35 \%$. Phytochemical screening showed that simplicia and extract contain alkaloids, flavonoids, and tannins. Shampoo of green tea leaves had light brown in color which homogen with 5.2-6.7 in $\mathrm{pH}$ range, $0.93-1.10 \mathrm{~g} / \mathrm{mL}$ in density, $1230-3910 \mathrm{cps}$ in viscosity, and not induced the skin and eye irritation. All the shampoo formula meet the criteria for a good shampoo. Formula F was selected as the best formula, because of highest extract concentration (15\%) and menthol ingredients.
\end{abstract}

Keywords: Irritation test, physical stability, secondary metabolites 


\section{Pendahuluan}

Rambut merupakan salah satu pendukung penampilan, sehingga harus dirawat agar tetap bersih dan sehat. Upaya perawatan rambut dapat dilakukan dengan sampo. Sampo digunakan untuk menghilangkan partikel yang tidak diinginkan, seperti minyak dan ketombe, tanpa pengelupasan sebum yang berlebihan karena dapat menyebabkan rambut menjadi sulit diatur. ${ }^{1}$ Tumbuhan mengandung metabolit sekunder yang lebih aman dibandingkan dengan bahan sintetik, sehingga sangat berguna untuk formulasi sampo dari bahan alam. Teh hijau memiliki aktivitas antibakteri dan anti kariogenik terhadap flora oral. ${ }^{2}$ Ekstrak kasar teh hijau memiliki aktivitas antifungi lebih tinggi dibandingkan ekstrak kasar teh hitam. ${ }^{3}$

Teh hijau memiliki daun berwarna hijau tua dan berbentuk oval dengan tepi bergerigi, sedangkan bunganya berwarna putih dan wangi. Polifenol dalam teh lebih dikenal sebagai flavanol atau katekin dan mengandung $30-40 \%$ padatan yang dapat terekstraksi. Katekin utama dalam teh hijau meliputi epikatekin, epikatekin-3galat, epigalokatekin, dan epigalokatekin3-galat. ${ }^{4,5}$ Teh hijau memiliki aktivitas antiaging, ${ }^{6} \quad$ antikanker, ${ }^{7} \quad$ antikaries, ${ }^{8}$ antibakteri, ${ }^{9}$ anti-Parkinson, ${ }^{10}$ dan efek kardiovaskular. ${ }^{11}$ Pusat Penelitian Teh dan Kina (PPTK) Gambung, Ciwidey, Jawa Barat, menghasilkan teh khas Gambung yang diolah menjadi teh hijau, hitam, dan putih. Penelitian ini bertujuan untuk mendukung diversifikasi produk teh untuk dikembangkan di PPTK Gambung. Pada penelitian ini dilakukan formulasi sampo dari ekstrak daun teh hijau yang stabil dan aman.

\section{Metode}

\section{Bahan}

Daun teh hijau (Camellia sinensis var. assamica) dikumpulkan dari Pusat Penelitian Teh dan Kina (PPTK) Gambung, Ciwidey, Jawa Barat. Natrium lauril sulfat, natrium klorida, polietilen glikol 400 (PEG400), nipagin, nipasol, dan mentol dibeli dari Dow Chemicals Company, Indonesia.

\section{Ekstraksi dan Penapisan Fitokimia}

Daun teh hijau dikeringkan di bawah sinar matahari secara tidak langsung selama lima hari.Sebanyak 500 g simplisia diekstraksi pada suhu $90^{\circ} \mathrm{C}$ selama 30 menit, kemudian disaring dan dipekatkan dengan rotary vaporator. Penapisan fitokimia dilakukan terhadap simplisia dan ekstrak menggunakan metode Farnsworth. ${ }^{12}$

\section{Pembuatan Sampo}

Basis sampo dibuat dengan mencampurkan seluruh bahan kecuali

Table 1 Formulasi Sampo Ekstrak Daun Teh Hijau

\begin{tabular}{lccccccc}
\hline \multirow{2}{*}{ Bahan (\%) } & \multicolumn{1}{c}{ Formula } \\
\cline { 2 - 8 } & $\mathrm{A}$ & $\mathrm{B}$ & $\mathrm{C}$ & $\mathrm{D}$ & $\mathrm{E}$ & $\mathrm{F}$ & $\mathrm{G}$ \\
\hline Ekstrak kental & 5 & 10 & 15 & 5 & 10 & 15 & - \\
Na-lauril sulfat & 1 & 1 & 1 & 2 & 2 & 2 & 2 \\
NaCl & 0,5 & 0,5 & 0,5 & 0,5 & 0,5 & 0,5 & 0,5 \\
PEG-400 & - & - & - & 1 & 1 & 1 & 1 \\
Nipagin & 0,18 & 0,18 & 0,18 & 0,18 & 0,18 & 0,18 & 0,18 \\
Nipasol & 0,02 & 0,02 & 0,02 & 0,02 & 0,02 & 0,02 & 0,02 \\
Mentol & - & - & - & 0,25 & 0,25 & 0,25 & - \\
Air suling sampai & 100 & 100 & 100 & 100 & 100 & 100 & 100 \\
\hline
\end{tabular}


ekstrak menggunakan homogenizer pada kecepatan $1000 \mathrm{rpm}$ dan waktu 10 menit. Ekstrak kental sesuai formula dimasukkan ke dalam mortir, ditambahkan sedikit basis, dan diaduk hingga homogen. Ekstrak yang telah didispersikan dalam basis dicampurkan ke dalam sisa basis dan diaduk kembali dengan homogenizer pada kecepatan 1000 rpm dan waktu 5 menit. Formula sampo yang dibuat tercantum pada Tabel 1 .

\section{Evaluasi Sampo}

\section{Pengamatan fisik. ${ }^{13}$}

Pengamatan organoleptis dilakukan selama 30 hari pada suhu kamar $\left(28-30^{\circ} \mathrm{C}\right)$, meliputi warna, aroma, dan homogenitas.

\section{Penentuan $\mathbf{p H} .^{13}$}

$\mathrm{pH}$ sampo diukur menggunakan $\mathrm{pH}$ meter terkalibrasi pada suhu konstan. Pengukuran dilakukan pada hari ke-0 dan 30.

\section{Penentuan viskositas. ${ }^{13}$}

Viskositas sampo ditentukan menggunakan viskometer Brookfield Viscometer. Spindle No. 7 pada kecepatan $60 \mathrm{rpm}$ dan suhu $25^{\circ} \mathrm{C}$. angka yang terbaca pada viskometer dicatat dan dikalikan dengan faktor yang diberikan dalam katalog viskometer.

\section{Pengukuran bobot jenis. ${ }^{13}$}

Bobot jenis sampo dibandingkan terhadap air suling diukur menggunakan piknometer pada suhu kamar $\left(28-30^{\circ} \mathrm{C}\right)$. Pengukuran dilakukan pada hari ke-0 dan 30 .

\section{Uji keamanan. ${ }^{13}$}

(a) Uji tempel (patch test) pada kulit punggungkelinciyangtelahdicukurbulunya. Sampo dilarutkan dalam air menjadi larutan $2 \%$ dan dioleskan pada punggung kelinci tersebut. Lokasi lekatan dibiarkan terbuka selama 24 jam, dan reaksi kulit yang terjadi diamati. Pengamatan dilakukan setiap hari selama 3 hari. (b) Uji iritasi terhadap mata kelinci. Sampo dilarutkan dalam air menjadi larutan 10\%. Sebanyak $0,1 \mathrm{~mL}$ sediaan yang telah diencerkan, diteteskan ke dalam salah satu kelopak mata kelinci dan kelopak mata yang lain digunakan sebagai kontrol negatif. Pengamatan dilakukan dengan bantuan senter selama 7 hari setelah penetesan, meliputi reaksi pada kornea, iris, dan konjungtiva mata. Reaksi pada kornea teramati dari kekeruhan pada iris dan berubahnya ukuran pupil atau bahkan adanya pendarahan pada iris. Reaksi pada konjungtiva adalah timbulnya kemerahan, pembengkakan, dan penutupan kelopak mata.

Tabel 2 Hasil Pengamatan Organoleptik, pH, dan Bobot Jenis

\begin{tabular}{cclcccc}
\hline Hari ke- & Formula & Warna & Bau & Homogenitas & pH & $\begin{array}{c}\text { Bobot jenis } \\
(\mathrm{g} / \mathrm{mL})\end{array}$ \\
\hline & A & Coklat muda & Teh hijau & Homogen & $6,7+0,1$ & $0,93+0,6$ \\
B & Coklat muda & Teh hijau & Homogen & $6,5+0,1$ & $1,00+0,1$ \\
& C & Coklat muda & Teh hijau & Homogen & $6,1+0,2$ & $1,05+0,4$ \\
D & Coklat & Teh + mentol & Homogen & $5,8+0,1$ & $1,05+0,1$ \\
& E & Coklat & Teh + mentol & Homogen & $5,6+0,1$ & $1,08+0,3$ \\
F & Coklat & Teh + mentol & Homogen & $5,2+0,1$ & $1,10+0,7$ \\
G & Bening & Tidak berbau & Homogen & $7,0+0,3$ & $1,06+0,1$ \\
& A & Coklat muda & Teh hijau & Homogen & $6,7+0,1$ & $0,96+0,1$ \\
B & Coklat muda & Teh hijau & Homogen & $6,5+0,2$ & $1,04+0,1$ \\
C & Coklat muda & Teh hijau & Homogen & $6,1+0,1$ & $1,08+0,8$ \\
D & Coklat & Teh + mentol & Homogen & $5,8+0,1$ & $1,09+0,1$ \\
E & Coklat & Teh + mentol & Homogen & $5,6+0,3$ & $1,11+0,2$ \\
F & Coklat & Teh + mentol & Homogen & $5,2+0,1$ & $1,13+0,2$ \\
G & Bening & Tidak berbau & Homogen & $7,0+0,1$ & $1,08+0,1$ \\
\hline
\end{tabular}




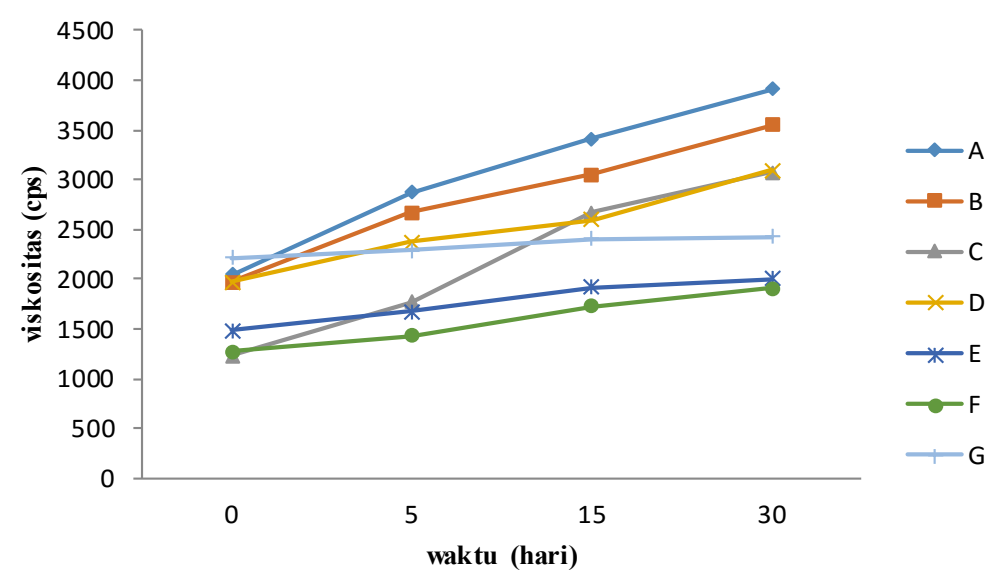

Gambar 1 Viskositas sampo selama pengamatan

\section{Hasil}

Karakterisasi simplisia menunjukkan adanya sel batu, rambut penutup, dan stomata yang khas pada daun teh hijau. Ekstraksi $500 \mathrm{~g}$ simplisia menghasilkan 175 g ekstrak kental dengan rendemen sebesar $35 \%$. Ekstrak kental daun teh hijau memiliki warna coklat tua dengan bau khas teh hijau. Hasil penapisan fitokimia menunjukkan kandungan metabolit sekunder dalam ekstrak sama dengan simplisia, yaitu alkaloid, flavonoid, dan tanin.

\section{Pembahasan}

Penapisan fitokimia dilakukan terhadap simplisia dan ekstrak untuk mengetahui pengaruh ekstraksi terhadap kandungan metabolit sekunder. Hasil penapisan fitokimia terhadap simplisia dan ekstrak menunjukkan hasil yang sama. Hal ini menunjukkan bahwa proses ekstraksi tidak mempengaruhi kandungan metabolit sekunder, karena metabolit sekunder dalam daun teh hijau stabil terhadap pemanasan pada suhu $90^{\circ} \mathrm{C}$ selama 30 menit.

Sampo ekstrak daun teh hijau yang diformulasikan dengan variasi ekstrak daun teh hijau dan variasi basis sampo dibandingkan terhadap formula pembanding $(\mathrm{G})$ yang tidak mengandung ekstrak daun teh hijau. Pengamatan terhadap organoleptik, $\mathrm{pH}$, dan bobot jenis hanya dilakukan pada hari ke-0 dan ke-30 karena sampo dibuat dengan menggunakan pengawet, yaitu nipagin dan nipasol, yang dapat menghambat pertumbuhan bakteri dan jamur sehingga diharapkan sampo tetap stabil selama penyimpanan. ${ }^{14}$ Hasil pengamatan stabilitas fisik selama 30 hari menunjukkan bahwa seluruh formula sampo homogen dan stabil dengan warna coklat muda hingga coklat dan bau khas teh hijau atau campuran bau teh hijau dan mentol atau tidak berbau (Tabel 2).

Sampo yang mengandung ekstrak daun teh hijau memiliki nilai $\mathrm{pH}$ 6,1-6,7, sampo yang mengandung campuran ekstrak daun teh hijau dan mentol memiliki $\mathrm{pH}$ 5,2-5,8, sedangkan sampo pembanding memiliki $\mathrm{pH} 7,0$. Nilai $\mathrm{pH}$ dipengaruhi oleh konsentrasi ekstrak daun teh hijau dan mentol. Semakin tinggi konsentrasi ekstrak daun teh hijau, maka $\mathrm{pH}$ semakin rendah. Hal ini disebabkan oleh semakin tingginya kandungan polifenol yang bersifat asam lemah, ${ }^{15}$ sehingga dapat menurunkan $\mathrm{pH}$. Pada formula D, E, dan F ditambahkan mentol memberikan efek mendinginkan karena 1-mentol langsung berinteraksi dengan reseptor dingin pada tubuh, dan mengurangi rasa gatal. ${ }^{14}$ Penambahan mentol menyebabkan penurunan $\mathrm{pH}$ karena mentol termasuk golongan fenol yang bersifat asam lemah, ${ }^{14}$ sehingga sampo yang ditambahkan mentol memiliki $\mathrm{pH}$ lebih rendah dibandingkan dengan sampo 
Tabel 3 Hasil Uji Keamanan Sampo

\begin{tabular}{lcccccccc}
\hline \multirow{2}{*}{ Jenis uji } & Hari & \multicolumn{9}{c}{ Formula } \\
\cline { 2 - 8 } & ke- & A & B & C & D & E & F & G \\
\hline \multirow{3}{*}{ Uji tempel } & 1 & - & - & - & - & - & - & - \\
& 2 & - & - & - & - & - & - & - \\
& 3 & - & - & - & - & - & - & - \\
& 1 & - & - & - & - & - & - & - \\
\multirow{3}{*}{ Uji iritasi } & 2 & - & - & - & - & - & - & - \\
& 3 & - & - & - & - & - & - & - \\
& 4 & - & - & - & - & - & - & - \\
& 5 & - & - & - & - & - & - & - \\
& 6 & - & - & - & - & - & - & - \\
& 7 & - & - & - & - & - & - & - \\
\hline
\end{tabular}

yang hanya mengandung ekstrak daun teh hijau (Tabel 2).

Bobot jenis sampo meningkat dengan meningkatnya konsentrasi ekstrak daun teh hijau. Semakin tinggi konsentrasi ekstrak daun teh hijau yang ditambahkan, maka semakin sedikit air dalam sampo, sehingga bobot jenis sampo semakin tinggi. Pengamatan terhadap bobot jenis menunjukkan bahwa bobot jenis seluruh sampo cukup stabil karena perubahan yang terjadi sangat kecil, sehingga tidak mempengaruhi homogenitas dan stabilitas sampo selama 30 hari (Tabel 2).

Bobot jenis sampo ekstrak teh hijau memenuhi persyaratan bobot jenis yang ditetapkan oleh Standar Nasional Indonesia untuk sediaan sampo, yaitu minimal 1,02, ${ }^{11}$ kecuali sampo dengan konsentrasi ekstrak $5 \%$. Hal ini disebabkan karena konsentrasi ekstrak yang rendah, sehingga volume air yang ditambahkan lebih banyak dan bobot jenis menjadi lebih kecil.

Semakin tinggi konsentrasi ekstrak daun teh hijau yang ditambahkan, maka semakin sedikit air yang ditambahkan, sehingga viskositas sampo semakin tinggi (Gambar 1). Formula A, B, dan C diformulasikan tanpa penambahan PEG400, sedangkan pada formula D, E, F, dan G ditambahkan PEG-400. PEG-400 berfungsi untuk meningkatkan viskositas sampo, ${ }^{14}$ dan melembabkan kulit kepala, karena penggunaan natrium lauril sulfat sebagai surfaktan dapat menghilangkan sebum dari kulit kepala, sehingga kulit kepala menjadi kering. Hasil pengamatan menunjukkan bahwa sampo yang mengandung PEG-400 memiliki tekstur lebih lembut dan sedikit berminyak dibandingkan dengan sampo tanpa PEG-400.

Sampo diformulasikan dengan natrium lauril sulfat sebagai surfaktan anionik dan zat pembasah pada konsentrasi 1-2\%, ${ }^{14}$ sehingga sampo yang dibuat dapat membentuk busa yang stabil. Natrium klorida konsentrasi $0,5 \%$ digunakan sebagai pengendali flokulasi suspensi $\mathrm{i}^{14}$ serta memperbaiki viskositas sampo karena dapat mempengaruhi karakter ionik sediaan. ${ }^{16}$

Hasil uji keamanan sampo menunjukkan bahwa tidak adanya reaksi kemerahan pada kulit punggung kelinci dan kulit tangan manusia. Sedangkan uji iritasi pada mata kelinci juga tidak menunjukkan reaksi kemerahan. Hal ini menunjukkan bahwa komponen dalam sampo tidak mengiritasi mukosa kulit dan konjungtiva mata.

\section{Simpulan}

Seluruh formula sampo memenuhi kriteria sampo yang baik. Formula F dipilih sebagai formula terbaik, karena mengandung konsentrasi ekstrak paling tinggi (15\%) dan mentol. 


\section{Daftar Pustaka}

1. Robbins CR. Chemical and physical behavior of human hair, 4th ed, Springer Verlag, New York, 2002, 21-45.

2. Kaur HP, Kaur S, Rana S. Antibacterial Activity and Phytochemical Profile of Green Tea, Black Tea and Divya Peya Herbal Tea. Int. J. Pure App. Biosci. 2015; 3(3): 117-23.

3. Cheruiyot SE, Muturi M, Bii C. Antifungal Activities of Camellia Sinensis Crude Extract on Selected Pathogenic and Mycotoxic Fungi. J Bacteriol Mycol. 2015; 2(2): 1015.

4. Cabrera C, Artacho R, Gimenez R. Beneficial effects of green tea - a review. J. Am. Coll. Nutr. 2006; 25(2): 79-99.

5. $\mathrm{Wu} \mathrm{AH}, \mathrm{Yu} \mathrm{MC}$. Tea, hormone-related cancers and endogenous hormone levels. Mol. Nutr. Food Res. 2006; 50(2): 160-69.

6. ZaveriNT. Green tea and its polyphenolic constituents: Medicinal uses in cancer and non-cancer applications. Life Sci. 2006; 78: 2073-80.

7. Kuzuhara T, Suganuma M, Fujiki H Green tea catechins as a chemical chaperone in cancer prevention. Cancer. Lett. 2008; 261: 12-20.

8. Duke JA. Handbook of Medicinal Herbs. 2nd ed. 2000. Florida: CRC Press. 353-54.
9. Almajano MP, Carbo R, Jimenez AP, Gordon MH. Antioxidant and antimicrobial activities of tea infusions. Food. Chem. 2008; 108: 55-63.

10. Bertoldi M, Gonsalvi M, Voltattorni CB. Green tea polyphenols: Novel irreversible inhibitors of dopa decarboxylase. Biochem. Biophys. Res. Commun. 2001; 284: 90-93.

11. Chansouria JPN, Hemalatha S, Ray AB. Medicinal Plants: Hypolipidemic, Hypocholesterolemic, and Antiatherosclerotic properties. Lucknow: Int. Book Distributing. 2000. 51-56.

12. Fransworth NR. Biological and Phytochemycal Screening of Plants. J. Pharm. Sci. 1966, 55: 225-86.

13. Standar Nasional Indonesia. Sampo. Jakarta: Dewan Standarisasi Nasional SP-115,1980, 1-5

14. Handbook of Pharmaceutical Excipients, London \& Chicago, Pharmaceutical Press \& American Pharmacists Association. 2009.

15. Harborne JB. Phytochemical Methods: A Guide to Modern Techniques of Plant Analysis, London, Thompson Science. 1998.

16. Okor RS. The effect of phenol on the electrolyte flocculation of certain polymeric dispersions to thixotropic gels. Pharm Res. 1993, 10: 220-22. 